\title{
Revised Reference Values for Potassium Intake
}

\author{
Daniela Strohm $^{\mathrm{a}}$ Sabine Ellinger ${ }^{\mathrm{b}}$ Eva Leschik-Bonnet ${ }^{\mathrm{a}}$ Friederike Maretzke $^{\mathrm{a}}$ \\ Helmut Heseker ${ }^{c}$ German Nutrition Society (DGE) \\ ${ }^{a}$ German Nutrition Society, Bonn, Germany; ${ }^{b}$ Faculty of Food, Nutrition and Hospitality Sciences, Hochschule \\ Niederrhein, University of Applied Sciences, Moenchengladbach, Germany; ' Department of Sports and Health, \\ University of Paderborn, Paderborn, Germany
}

\section{Keywords}

Potassium · Nutrient intake $\cdot$ Reference value

\begin{abstract}
Background: The nutrition societies of Germany, Austria and Switzerland have revised the reference values for potassium intake in January 2017. Methods: For adults, the estimated value was based on the 24-h urinary potassium excretion and on preventive considerations regarding hypertension and stroke. The estimated values for children and adolescents were extrapolated from the adult estimated value considering differences in body mass. For infants aged 0 to under 4 months, the estimated value was set based on the potassium intake via breast milk. From this reference value, the estimated value for infants aged 4 to under 12 months was also derived by extrapolation. The estimated value for lactating women takes into account the potassium loss via breast milk. Results: The estimated values for potassium intake are set at $400 \mathrm{mg} /$ day for breastfed infants aged 0 to under 4 months, $600 \mathrm{mg} /$ day for infants aged 4 to under 12 months, 1,100-4,000 mg/day for children and adolescents, 4,000 mg/day for adults and pregnant women and $4,400 \mathrm{mg} / \mathrm{day}$ for lactating women. Conclusions: The con-
\end{abstract}

\section{KARGER}

E-Mail karger@karger.com www.karger.com/anm

\section{The Author(s) \\ Published by S. Karger AG, Basel \\ Karger \\ Open access}

This article is licensed under the Creative Commons AttributionNonCommercial-NoDerivatives 4.0 International License (CC BYNC-ND) (http://www.karger.com/Services/OpenAccessLicense) Usage and distribution for commercial purposes as well as any distribution of modified material requires written permission. sumption of potassium-rich foods should be generally increased. Supplemental intake beyond the estimated values has no health benefit and is therefore not recommended.

C 2017 The Author(s)

Published by S. Karger AG, Basel

\section{Introduction}

The D-A-CH 'reference values for nutrient intake' [1] are jointly issued by the nutrition societies of Germany, Austria and Switzerland (the abbreviation D-A-CH arises from the initial letters of the common country identification for the countries Germany [D], Austria [A] and Switzerland $[\mathrm{CH}]$ ). Previously, the 'reference values for nutrient intake' were revised for vitamin D [2], calcium [3], folate [4], vitamin C [5], energy [6], selenium [7], thiamin, riboflavin and niacin [8]. The revised reference values for potassium were published in German in January 2017 [1].

Quantitatively, potassium is the main electrolyte in the intracellular space where it is present as water-soluble potassium ion $\left(\mathrm{K}^{+}\right)$and serves to maintain osmotic pressure, electrolyte homoeostasis and acid-base bal- 
ance [9]. By maintaining a high intracellular potassium concentration, the $\mathrm{Na}^{+} / \mathrm{K}^{+}$-ATPase generates a membrane potential. Control of this electrochemical gradient is essential for the transmission of neural impulses and thus for muscle contraction, heart function and blood pressure regulation $[10,11]$. Moreover, potassium is a cofactor of several enzymes involved in protein and glycogen synthesis and plays therefore a crucial role in growth $[9,10]$.

\section{Criteria to Assess Potassium Supply}

Due to potassium homoeostasis, plasma concentration of potassium is not suitable to provide information on potassium intake (or status). Instead, the measurement of 24-h urinary potassium excretion is considered the gold standard method for assessment of potassium intake [12-14]. However, 24-h urine collections are complex and require a high level of compliance. To determine potassium intake in an individual using renal potassium excretion, several 24 -h urine samples would be required. Therefore, this method is of limited suitability for large population studies. Thus, in order to assess the potassium intake of the general population, 24-h potassium excretion is often estimated based on spot urinary potassium concentrations. However, due to the possible over- or underestimation of potassium excretion, spot urine samples provide relatively inaccurate estimates of potassium intake in individuals [1517].

\section{Derivation of the Reference Values for Potassium Intake}

\section{Adults}

There is no experimental data on the potassium requirement in adults. It is therefore not possible to set an average requirement and the reference value for potassium intake is set as estimated value. The potassium intake observed in men and women in Germany is used as a basis to derive the estimated value for potassium intake for adults.

Current data on potassium excretion in spot urine is available from the German Health Interview and Examination Survey for Adults (DEGS1; 2008-2011), which provides nationally representative health data of 7,988 adults aged between 18 and 79 years living in Germany [18]. Thus, taking into account a creatinine correction factor, the dietary intake of potassium can be estimated $[18,19]$. In addition, the urinary potassium excretion has to be corrected by the absorption and the excretion rate of potassium. For this, a conversion factor of 1.3 was chosen based on 2 studies $[13,20]$ and by following the approach of the World Health Organization (WHO) [21] and the European Food Safety Authority (EFSA) [17]. This results in an estimated median potassium intake of approximately $3,900 \mathrm{mg} /$ day for women (5th [P5] to 95th percentiles [P95]: $1,800-8,000 \mathrm{mg} /$ day) and approximately 4,300 $\mathrm{mg} /$ day for men (P5-P95: 2,000$8,000 \mathrm{mg} /$ day).

Due to the uncertainty of potassium excretion measurement based on spot urine sample data from DEGS1, additional preventive aspects regarding hypertension and stroke are taken into account for deriving the reference value for adults.

There is evidence for an association between high potassium intake (intake from supplements and from foods) and prevention of hypertension [22, 23]. A metaanalysis by the WHO [24] ${ }^{1}$ of 21 randomised controlled intervention studies reported a reduction in systolic blood pressure of $3.5 \mathrm{~mm} \mathrm{Hg}$ (95\% CI 1.8-5.2) and in diastolic blood pressure of $2.0 \mathrm{~mm} \mathrm{Hg}$ (95\% CI 0.9-3.1) at increased potassium intake, which has been determined by 24 -h urinary potassium excretion. The strongest association was observed at a potassium intake of $3,500-4,700 \mathrm{mg} /$ day. The meta-analysis included 16 studies with hypertensive patients (blood pressure $\geq 140 / 90 \mathrm{~mm} \mathrm{Hg}$ ), 3 with normotensive subjects and 2 with both hyper- and normotensive subjects. Subgroup analyses demonstrated significant blood pressure-lowering effects in hypertensive patients, while there was no effect on systolic and diastolic blood pressure in normotensive subjects [24]. In general, the antihypertensive effect of potassium is greater at a sodium intake exceeding $4,000 \mathrm{mg} /$ day than at a sodium intake of $2,000-4,000 \mathrm{mg} /$ day $[24,27]$.

In a prospective cohort study that was published after the WHO meta-analysis [28], a potassium intake of less than $3,500 \mathrm{mg}$ /day was associated with higher risk of hypertension than a potassium intake of more than 3,500 $\mathrm{mg} /$ day in 5,511 Dutch normotensive subjects (part of the PREVEND study). Potassium intake in this study was estimated from several 24-h urinary collections.

Furthermore, evidence for an association between high potassium intake and stroke prevention has been

\footnotetext{
${ }^{1}$ The results of the systematic reviews by the WHO [24-26] were also published by Aburto et al. [21].
} 
reported in several studies, including a pooled analysis of cohort studies [29], an analysis of the Nurses' Health Study I and II [30], and the Women's Health Initiative Study [31]. The association appears to be stronger in normotensive than in hypertensive individuals [31]. The $\mathrm{WHO}^{2}$ meta-analysis of cohort studies [25], which included studies in normotensive and hypertensive subjects, reported that high potassium intake was associated with reduced risk of stroke. The strongest association was observed at a potassium intake of 3,500-4,700 $\mathrm{mg} /$ day.

These data on potassium intake and risk of hypertension and stroke indicates that the effect in the general population is largest at a potassium intake of 3,500-4,700 $\mathrm{mg} /$ day. Potassium intake in the general population estimated by potassium excretion observed in men and women in Germany (from DEGS1) is within this range [19]. Therefore, considering the high prevalence of hypertension in Germany (approximately 30\%) [32, 33], the estimated value for potassium intake is set to 4,000 $\mathrm{mg} /$ day for men and women (Table 1). It is not considered useful to specify different values for men and women. The value of $4,000 \mathrm{mg} /$ day derived as the estimated value is within the intake range considered having preventive effects $(3,500-4,700 \mathrm{mg} /$ day $)$. The exact mean value of this range is not indicated, since it reflects an accuracy that is not available on the basis of the current data.

\section{Children and Adolescents}

No experimental data is available on the potassium requirement in children and adolescents. Therefore, the reference values for children and adolescents are based on the values compiled for adults and taking into account differences in body weight and growth factors to consider the requirements for growth (Table 2). Growth factors at the different ages were calculated as the proportional increase in protein requirement for growth relative to the maintenance requirement according to WHO $[1,34]$. It is not considered useful to specify different values for boys and girls. When using the age groups and reference body weights, the $\mathrm{D}-\mathrm{A}-\mathrm{CH}$ reference values are based upon [1], the resulting estimated values for potassium intake range from $1,100 \mathrm{mg} /$ day (for 1 - to under 4 -year-olds) to $4,000 \mathrm{mg} / \mathrm{day}$ (for 15- to under 19-yearolds; Tables 1,2).

\footnotetext{
${ }^{2}$ The meta-analysis of cohort studies by the WHO included only the results of studies in the statistical analysis that had not been adjusted for blood pressure values $[21,32]$.
}

Table 1. Estimated values for adequate potassium intake

\begin{tabular}{lc}
\hline Age & Potassium ${ }^{\mathrm{a}}, \mathrm{mg} /$ day \\
\hline Infants & \\
0 to under 4 months & 400 \\
4 to under 12 months & 600 \\
Children and adolescents & \\
1 to under 4 years & 1,100 \\
4 to under 7 years & 1,300 \\
7 to under 10 years & 2,000 \\
10 to under 13 years & 2,900 \\
13 to under 15 years & 3,600 \\
15 to under 19 years & 4,000 \\
Adults & \\
19 to under 25 years & 4,000 \\
25 to under 51 years & 4,000 \\
51 to under 65 years & 4,000 \\
65 years and older & 4,000 \\
Pregnant women & 4,000 \\
Lactating women & 4,400 \\
\hline
\end{tabular}

a $39.1 \mathrm{mg}$ potassium correspond to $1 \mathrm{mmol}$ potassium.

\section{Infants}

The reference values for potassium intake for infants aged 0 to under 4 months were derived from the potassium content of breast milk, which is considered to be the optimal diet for infants $[36,37]$. The reference values for infants are therefore estimated values. The average breast milk intake of an exclusively breastfed infant is 750 $\mathrm{mL} /$ day [38]. Based on a mean potassium content of breast milk of $50 \mathrm{mg} / 100 \mathrm{~mL}$ within the first 4 months [39-45], the estimated value for potassium intake for breastfed infants aged 0 to under 4 months is set at $400 \mathrm{mg} /$ day (Table 1).

The consumption of breast milk declines along with the introduction of solid foods. Since no data is available from Germany with regard to potassium intake via solid foods, the estimated value for infants aged 0 to under 4 months is used to derive the reference value for infants over 4 months of age (Table 3). Taking into account the differences in average body weight, an estimated value of $600 \mathrm{mg}$ /day for infants aged 4 to under 12 months was derived (Tables 1,3 ).

\section{Pregnancy}

There is limited potassium accumulation during pregnancy $[47,48]$. Thus, the estimated value for potassium intake for pregnant women does not differ from that for non-pregnant women and is set to 4,000 $\mathrm{mg} /$ day. 
Table 2. Estimated values for potassium intake for children and adolescents taking into account differences in average body weight and growth factors

\begin{tabular}{|c|c|c|c|c|c|}
\hline Age, years & Gender & $\begin{array}{l}\text { Reference body } \\
\text { weight, } \mathrm{kg}^{\mathrm{a}}[1]\end{array}$ & $\begin{array}{l}\text { Growth } \\
\text { factor }^{b}[1]\end{array}$ & $\begin{array}{l}\text { Potassium intake } \\
\text { considering reference } \\
\text { body weight and } \\
\text { growth factors, } \\
\mathrm{mg} / \text { dayc }^{c}\end{array}$ & $\begin{array}{l}\text { Estimated value } \\
\text { for potassium } \\
\text { intake (rounded), } \\
\text { mg/day }\end{array}$ \\
\hline \multirow[t]{2}{*}{1 to under 4} & Male & 13.9 & 0.25 & 983 & \multirow[t]{2}{*}{1,000} \\
\hline & Female & 13.2 & 0.25 & 1,100 & \\
\hline \multirow[t]{2}{*}{4 to under 7} & Male & 20.2 & 0.06 & 1,212 & \multirow[t]{2}{*}{1,300} \\
\hline & Female & 20.1 & 0.06 & 1,421 & \\
\hline \multirow[t]{2}{*}{7 to under 10} & Male & 29.3 & 0.13 & 1,875 & \multirow[t]{2}{*}{2,000} \\
\hline & Female & 28.7 & 0.13 & 2,165 & \\
\hline \multirow[t]{2}{*}{10 to under 13} & Male & 41.0 & 0.13 & 2,624 & \multirow[t]{2}{*}{2,900} \\
\hline & Female & 42.1 & 0.11 & 3,119 & \\
\hline \multirow[t]{2}{*}{13 to under 15} & Male & 55.5 & 0.10 & 3,449 & \multirow[t]{2}{*}{3,600} \\
\hline & Female & 54.0 & 0.07 & 3,845 & \\
\hline \multirow[t]{2}{*}{15 to under 19} & Male & 69.2 & 0.07 & 4,182 & \multirow[t]{2}{*}{4,000} \\
\hline & Female & 59.5 & 0.02 & 4,057 & \\
\hline \multicolumn{6}{|c|}{$\begin{array}{l}\text { a The reference values for body weight correspond to the median body weight determined in the German } \\
\text { Health Interview and Examination Survey for Children and Adolescents in Germany (KiGGS; 2003-2006) [35]. } \\
\text { In each case, the values reflect the mid-point of the respective age range. } \\
{ }^{b} \text { Growth factors at the different ages were calculated as the proportional increase in protein requirement for } \\
\text { growth relative to the maintenance requirement according to the WHO }[1,34] \text {. } \\
{ }^{c} \text { Calculated from: estimated value }{ }_{\text {adults }} \times(\text { reference body weight } \\
\left.\text { (1 + grildren/adolescents } / \text { reference body weight }_{\text {adults }}\right) \times \\
\text { under } 51 \text { years): men } 70.7 \mathrm{~kg} \text {, women } 60.0 \mathrm{~kg}[1] \text {. }\end{array}$} \\
\hline
\end{tabular}

Table 3. Estimated values for potassium intake for infants aged 4 to under 12 months

\begin{tabular}{lllll}
\hline $\begin{array}{l}\text { Age, } \\
\text { months }\end{array}$ & Gender & $\begin{array}{l}\text { Reference body } \\
\text { weight, } \mathrm{kg}^{\mathrm{a}}[\mathrm{1}]\end{array}$ & $\begin{array}{l}\text { Potassium intake considering } \\
\text { reference body weights }{ }^{\mathrm{b}}, \mathrm{mg} / \mathrm{day}\end{array}$ & $\begin{array}{l}\text { Estimated value for potassium } \\
\text { intake (rounded), mg/day }\end{array}$ \\
\hline \multirow{2}{*}{ to under 12 } & Male & 8.6 & 614 & 600 \\
& Female & 7.9 & 620 & \\
\hline
\end{tabular}

\footnotetext{
a The reference values for body weight correspond to the median body weight of the WHO child growth standards [46] for the age of 8 months.

${ }^{\mathrm{b}}$ Calculated from: estimated value ${ }_{0-4 \text { months }} \times\left(\right.$ reference body weight ${ }_{4-12 \text { months }} /$ reference body weight $_{0-4}$ months $)$. Estimated value ${ }_{0-4}$ months: $400 \mathrm{mg} /$ day (Table 1 ). Reference body weight ${ }_{0-4}$ months: male $5.6 \mathrm{~kg}$; female $5.1 \mathrm{~kg}$ [1].
}

\section{Lactation}

The potassium requirement in women is increased during lactation due to the amount that is secreted with breast milk. Approximately $375 \mathrm{mg}$ potassium/day is secreted with breast milk. Considering a potassium bioavailability of $85 \%$ [20, 49], an additional $400 \mathrm{mg}$ potassium/day is required during lactation. Thus, the estimated value for potassium intake for lactating women amounts to $4,400 \mathrm{mg} / \mathrm{day}$ (Table 1). 


\section{Preventive Aspects}

In the following paragraphs, current available data on potassium is outlined in association with other healthrelated aspects in addition to the ones used for deriving the reference values.

Regarding the prevention of hypertension, there was no significant effect of increased potassium intake on blood pressure in children in the meta-analysis of intervention studies by the WHO [26]. In cohort studies, high potassium intake was associated with an attenuated agedependent increase in blood pressure in children and adolescent girls $[50,51]$.

Results regarding the association between potassium intake and risk of cardiovascular diseases are contradictory. There was no significant association between potassium intake and risk of cardiovascular diseases or coronary heart diseases in the WHO metaanalysis [25] of cohort studies in normotensive and hypertensive subjects. Similarly, urinary potassium excretion was not associated with cardiovascular diseases risk in a cohort study that was published after the WHO meta-analysis [14]. In contrast, higher urinary potassium excretion ( $>3$ vs. $<1.5 \mathrm{~g} /$ day) was associated with significantly lower risk of mortality and cardiovascular diseases in the large international Prospective Urban Rural Epidemiology cohort study [52], which was also published after the WHO meta-analysis [25].

Even though data on the direct effects of potassium intake on cardiovascular disease risk is inconclusive, high potassium intake may indirectly modulate cardiovascular disease risk via its favourable effect on blood pressure [27], as hypertension is one of the main cardiovascular diseases risk factors $[11,53,54]$.

Data regarding the association between potassium intake and bone health is contradictory [55-58]. EFSA has recently highlighted that there is a lack of evidence regarding the association between potassium intake and risk of fracture and concludes that data regarding the association between intake of potassium supplements and bone density is inconsistent and thus, the evidence is insufficient [17].

EFSA also investigated the association between potassium intake and risk of kidney stones [17]. Several cohort studies indicate an association between low potassium intake and increased risk of kidney stones [59-61]. However, intervention studies failed to demonstrate an independent effect of potassium intake on the risk of kidney stones $[17,62,63]$.
Several prospective cohort studies investigated the association between potassium intake and risk of type $2 \mathrm{di}$ abetes mellitus [64-68]. However, the results are inconsistent and evidence regarding this association is insufficient [17].

\section{Discussion and Conclusion}

Based on the measurement of urinary potassium excretion, current data from DEGS1 of women and men in Germany show that the average potassium intake in the general population is $3,900 \mathrm{mg} /$ day in women and $4,300 \mathrm{mg} /$ day in men. For a potassium intake between 3,500 and $4,700 \mathrm{mg} /$ day, there is evidence for a preventive effect on hypertension and stroke. Therefore, considering the high prevalence of hypertension in Germany, the estimated value for potassium intake for adults is set to 4,000 $\mathrm{mg} /$ day. Thus, the consumption of unprocessed foods, such as vegetables and fruits, should be generally increased and the consumption of processed foods reduced in order to achieve a diet rich in potassium and low in other ingredients (e.g. salt). This is achievable as part of a balanced, wholesome diet. Supplemental intake beyond the estimated values for potassium intake has no additional health benefit and is therefore not recommended.

\section{Acknowledgement}

The authors thank Anna M. Amini, Professor Dr. Helmut Erbersdobler, Professor Dr. Hans Hauner, Professor Dr. Dr. HansGeorg Joost, Professor Dr. Stefan Lorkowski, Birte PetersonSperlich, Professor Dr. Gabriele I. Stangl, and Professor Dr. Bernhard Watzl for their valuable suggestions and contribution to the preparation of the revised reference values for potassium intake.

\section{Disclosure Statement}

The authors have no conflicts of interest to declare.

References

1 Deutsche Gesellschaft für Ernährung, Österreichische Gesellschaft für Ernährung, Schweizerische Gesellschaft für Ernährung (eds): Referenzwerte für die Nährstoffzufuhr, ed 2. Bonn, 2016.

2 German Nutrition Society: New reference values for vitamin D. Ann Nutr Metab 2012; 60:241-246.

3 German Nutrition Society: New reference values for calcium. Ann Nutr Metab 2013;63: 186-192. 
4 Krawinkel MB, Strohm D, Weissenborn A, Watzl B, Eichholzer M, Bärlocher K, Elmadfa I, Leschik-Bonnet E, Heseker H: Revised DA-CH intake recommendations for folate: how much is needed? Eur J Clin Nutr 2014;68: 719-723.

5 German Nutrition Society: New reference values for vitamin C intake. Ann Nutr Metab 2015;67:13-20.

6 German Nutrition Society: New reference values for energy intake. Ann Nutr Metab 2015;66:219-223.

7 Kipp AP, Strohm D, Brigelius-Flohe R, Schomburg L, Bechthold A, Leschik-Bonnet E, Heseker H: Revised reference values for selenium intake. J Trace Elem Med Biol 2015; 32:195-199.

8 Strohm D, Bechthold A, Isik N, Leschik-Bonnet $\mathrm{E}$, Heseker $\mathrm{H}$ : Revised reference values for the intake of thiamin (vitamin B1), riboflavin (vitamin B2), and niacin. NFS J 2016;3:20-24.

9 Strain JJ, Cashman KD: Minerals and trace elements; in Gibney MJ, Lanham-New SA, Cassidy A, Vorster HH (eds): Introduction to Human Nutrition, ed 2. The Nutrition Society Textbook Series. Chichester, Wiley-Blackwell, 2009, pp 188-237.

10 Pohl HR, Wheeler JS, Murray HE: Sodium and potassium in health and disease. Met Ions Life Sci 2013;13:29-47.

11 Whelton PK: Sodium, potassium, blood pressure, and cardiovascular disease in humans. Curr Hypertens Rep 2014;16:465.

12 Clark AJ, Mossholder S: Sodium and potassium intake measurements: dietary methodology problems. Am J Clin Nutr 1986;43:470476.

13 Tasevska N, Runswick SA, Bingham SA: Urinary potassium is as reliable as urinary nitrogen for use as a recovery biomarker in dietary studies of free living individuals. J Nutr 2006; 136:1334-1340.

14 Kieneker LM, Gansevoort RT, Boer RA de, Brouwers FP, Feskens EJ, Geleijnse JM, Navis G, Bakker SJ, Joosten MM: Urinary potassium excretion and risk of cardiovascular events. Am Clin J Nutr 2016;103:1204-1212.

15 Mente A, O'Donnell MJ, Dagenais G, Wielgosz A, Lear SA, McQueen MJ, Jiang Y, Xingyu W, Jian B, Calik KBT, Akalin AA, Mony P, Devanath A, Yusufali AH, LopezJaramillo P, Avezum A, JR, Yusoff K, Rosengren A, Kruger L, Orlandini A, Rangarajan S, Teo K, Yusuf S: Validation and comparison of three formulae to estimate sodium and potassium excretion from a single morning fasting urine compared to 24 -h measures in 11 countries. J Hypertens 2014;32:1005-1014.

16 Hooft van Huysduynen EJ, Hulshof PJ, van Lee L, Geelen A, Feskens EJ, van 't Veer P, van Woerkum CJ, de Vries JH: Evaluation of using spot urine to replace $24 \mathrm{~h}$ urine sodium and potassium excretions. Public Health Nutr 2014; 17:2505-2511.

17 European Food Safety Authority: Dietary reference values for potassium. EFSA J 2016;14: 4592.
18 Mensink GB, Klenow S, Schlaud M: Versorgungssituation der deutschen Bevölkerung mit ausgewählten Nährstoffen anhand der Ergebnisse der Studie zur Gesundheit Erwachsener in Deutschland (DEGS): Kalium; in Deutsche Gesellschaft für Ernährung (ed): 13. Ernährungsbericht 2016. Bonn, 2016, pp 57-59.

19 Johner SA, Boeing H, Thamm M, Remer T: Urinary $24-\mathrm{h}$ creatinine excretion in adults and its use as a simple tool for the estimation of daily urinary analyte excretion from analyte/creatinine ratios in populations. Eur J Clin Nutr 2015;69:1336-1343.

20 Holbrook JT, Patterson KY, Bodner JE, Douglas LW, Veillon C, Kelsay JL, Mertz W, Smith JC Jr: Sodium and potassium intake and balance in adults consuming self-selected diets. Am J Clin Nutr 1984;40:786-793.

21 Aburto NJ, Hanson S, Gutierrez H, Hooper L, Elliott P, Cappuccio FP: Effect of increased potassium intake on cardiovascular risk factors and disease: systematic review and metaanalyses. BMJ 2013;346:f1378.

22 Geleijnse JM, Kok FJ, Grobbee DE: Blood pressure response to changes in sodium and potassium intake: a metaregression analysis of randomised trials. J Hum Hypertens 2003; 17:471-480.

23 Whelton PK, He J, Cutler JA, Brancati FL, Appel LJ, Follmann D, Klag MJ: Effects of oral potassium on blood pressure. Meta-analysis of randomized controlled clinical trials. JAMA 1997;277:1624-1632.

24 World Health Organization: Effect of Increased Potassium Intake on Blood Pressure, Renal Function, Blood Lipids and Other Potential Adverse Effects. Genf, World Health Organization, 2012.

25 World Health Organization: Effect of Increased Potassium Intake on Cardiovascular Disease, Coronary Heart Disease and Stroke. Genf, World Health Organization, 2012.

26 World Health Organization: Effect of Increased Potassium Intake on Blood Pressure and Potential Adverse Effects in Children. Genf, World Health Organization, 2012.

27 World Health Organization: Guideline. Potassium Intake for Adults and Children: Potassium Intake for Adults and Children. Genf, World Health Organization, 2012.

28 Kieneker LM, Gansevoort RT, Mukamal KJ, de Boer RA, Navis G, Bakker SJ, Joosten MM: Urinary potassium excretion and risk of developing hypertension: the prevention of renal and vascular end-stage disease study. Hypertension 2014;64:769-776.

29 D'Elia L, Iannotta C, Sabino P, Ippolito R: Potassium-rich diet and risk of stroke: updated meta-analysis. Nutr Metab Cardiovasc Dis 2014;24:585-587.

30 Adebamowo SN, Spiegelman D, Willett WC, Rexrode KM: Association between intakes of magnesium, potassium, and calcium and risk of stroke: 2 cohorts of US women and updated meta-analyses. Am J Clin Nutr 2015;101: 1269-1277.
31 Seth A, Mossavar-Rahmani Y, Kamensky V, Silver B, Lakshminarayan K, Prentice R, van Horn L, Wassertheil-Smoller S: Potassium intake and risk of stroke in women with hypertension and nonhypertension in the women's health initiative. Stroke 2014;45:2874-2880.

32 Strohm D, Boeing H, Leschik-Bonnet E, Heseker H, Arens-Azevêdo U, Bechthold A, Knorpp L, Kroke A: Speisesalzzufuhr in Deutschland, gesundheitliche Folgen und resultierende Handlungsempfehlung. Ernaehrungs Umschau 2016;63:M146-M154.

33 Neuhauser H, Thamm M, Ellert U: Blutdruck in Deutschland 2008-2011: Ergebnisse der Studie zur Gesundheit Erwachsener in Deutschland (DEGS1). Bundesgesundheitsbl Gesundheitsforsch Gesundheitsschutz 2013; 56:795-801.

34 World Health Organization: Protein and Amino Acid Requirements in Human Nutrition. Genf, World Health Organization, 2007.

35 Robert Koch-Institut: Referenzperzentile für anthropometrische Maßzahlen und Blutdruck aus der Studie zur Gesundheit von Kindern und Jugendlichen in Deutschland (KiGGS) 2003-2006. Berlin, Robert Koch-Institut, 2011.

36 Bührer C, Genzel-Boroviczény O, Jochum F, Kauth T, Kersting M, Koletzko B, Mihatsch W, Przyrembel H, Reinehr T, Zimmer P: Ernährung gesunder Säuglinge. Monatsschr Kinderheilkd 2014;162:527-538.

37 Butte NF, Lopez-Alarcon MG, Garza C: Nutrient Adequacy of Exclusive Breastfeeding for the Term Infant during the First Six Months of Life, 2002. www.who.int/nutrition/publications/infantfeeding/nut_adequacy_of_exc_bfeeding_eng.pdf (accessed June $25,2013)$.

38 Neville MC, Keller R, Seacat J, Lutes V, Neifert M, Casey C, Allen J, Archer P: Studies in human lactation: milk volumes in lactating women during the onset of lactation and full lactation. Am J Clin Nutr 1988;48:1375-1386.

39 Gross SJ, David RJ, Bauman L, Tomarelli RM: Nutritional composition of milk produced by mothers delivering preterm. J Pediatr 1980; 96:641-644.

40 Picciano MF, Calkins EJ, Garrick JR, Deering RH: Milk and mineral intakes of breastfed infants. Acta Paediatr Scand 1981;70:189-194.

41 Keenan BS, Buzek SW, Garza C, Potts E, Nichols BL: Diurnal and longitudinal variations in human milk sodium and potassium: implication for nutrition and physiology. Am J Clin Nutr 1982;35:527-534.

42 Lemons JA, Moye L, Hall D, Simmons M: Differences in the composition of preterm and term human milk during early lactation. Pediatr Res 1982;16:113-117.

43 Dewey KG, Lönnerdal B: Milk and nutrient intake of breast-fed infants from 1 to 6 months: relation to growth and fatness. J Pediatr Gastroenterol Nutr 1983;2:497-506.

44 Bauer J, Gerss J: Longitudinal analysis of macronutrients and minerals in human milk produced by mothers of preterm infants. Clin Nutr 2011;30:215-220. 
45 Souci SW, Fachmann W, Kraut H (eds): Food Composition and Nutrition Tables, ed 8, Revised. Stuttgart, WVG, 2015.

46 World Health Organization: WHO Child Growth Standards - Length/Height-for-Age, Weight-for-Age, Weight-for-Length, Weightfor-Height and Body Mass Index-for-Age. Genf, World Health Organization, 2006.

47 Lindheimer MD, Richardson DA, Ehrlich EN, Katz AI: Potassium homeostasis in pregnancy. J Reprod Med 1987;32:517-522.

48 Forsum E, Sadurskis A, Wager J: Resting metabolic rate and body composition of healthy Swedish women during pregnancy. Am J Clin Nutr 1988;47:942-947.

49 Aizman R, Grahnquist L, Celsi G: Potassium homeostasis: ontogenic aspects. Acta Paediatr 1998;87:609-617.

50 Geleijnse JM, Grobbee DE, Hofman A: Sodium and potassium intake and blood pressure change in childhood. BMJ 1990;300:899-902.

51 Buendia JR, Bradlee ML, Daniels SR, Singer MR, Moore LL: Longitudinal effects of dietary sodium and potassium on blood pressure in adolescent girls. JAMA Pediatr 2015;169: 560-568.

52 O'Donnell M, Mente A, Rangarajan S, McQueen MJ, Wang X, Liu L, Yan H, Lee SF, Mony P, Devanath A, Rosengren A, LopezJaramillo P, Diaz R, Avezum A, Lanas F, Yusoff $\mathrm{K}$, Iqbal R, Ilow R, Mohammadifard N, Gulec S, Yusufali AH, Kruger L, Yusuf R, Chifamba J, Kabali C, Dagenais G, Lear SA, Teo K, Yusuf S: Urinary sodium and potassium excretion, mortality, and cardiovascular events. N Engl J Med 2014;371:612623.

53 Rahimi K, Emdin CA, MacMahon S: The epidemiology of blood pressure and its world- wide management. Circ Res 2015;116:925936.

54 Stokes J, Kannel WB, Wolf PA, D’Agostino $\mathrm{RB}$, Cupples LA: Blood pressure as a risk factor for cardiovascular disease. The Framingham study - 30 years of follow-up. Hypertension 1989;13(suppl):I13-I18.

55 Weaver CM: Potassium and health. Adv Nutr 2013;4:368-377.

56 Hayhoe RP, Lentjes MA, Luben RN, Khaw KT, Welch AA: Dietary magnesium and potassium intakes and circulating magnesium are associated with heel bone ultrasound attenuation and osteoporotic fracture risk in the EPIC-Norfolk cohort study. Am J Clin Nutr 2015;102:376-384.

57 Moseley KF, Weaver CM, Appel L, Sebastian A, Sellmeyer DE: Potassium citrate supplementation results in sustained improvement in calcium balance in older men and women. J Bone Miner Res 2013;28:497-504.

58 Lambert H, Frassetto L, Moore JB, Torgerson D, Gannon R, Burckhardt P, Lanham-New S: The effect of supplementation with alkaline potassium salts on bone metabolism: a metaanalysis. Osteoporos Int 2015;26:1311-1318.

59 Taylor EN, Stampfer MJ, Curhan GC: Dietary factors and the risk of incident kidney stones in men: new insights after 14 years of follow-up. J Am Soc Nephrol 2004;15:32253232.

60 Curhan GC, Willett WC, Speizer FE, Spiegelman D, Stampfer MJ: Comparison of dietary calcium with supplemental calcium and other nutrients as factors affecting the risk for kidney stones in women. Ann Intern Med 1997; 126:497-504.

61 Hirvonen T, Pietinen P, Virtanen M, Albanes D, Virtamo J: Nutrient intake and use of bever- ages and the risk of kidney stones among male smokers. Am J Epidemiol 1999;150:187-194.

62 Phillips R, Hanchanale VS, Myatt A, Somani B, Nabi G, Biyani CS: Citrate salts for preventing and treating calcium containing kidney stones in adults. Cochrane Database Syst Rev 2015;10:CD010057.

63 Maalouf NM, Moe OW, Adams-Huet B, Sakhaee K: Hypercalciuria associated with high dietary protein intake is not due to acid load. J Clin Endocrinol Metab 2011;96:3733-3740.

$64 \mathrm{Hu}$ G, Jousilahti P, Peltonen M, Lindstrom J, Tuomilehto J: Urinary sodium and potassium excretion and the risk of type 2 diabetes: a prospective study in Finland. Diabetologia 2005;48:1477-1483.

65 Colditz GA, Manson JE, Stampfer MJ, Rosner B, Willett WC, Speizer FE: Diet and risk of clinical diabetes in women. Am J Clin Nutr 1992;55:1018-1023.

66 Chatterjee R, Yeh HC, Shafi T, Selvin E, Anderson C, Pankow JS, Miller E, Brancati F: Serum and dietary potassium and risk of incident type 2 diabetes mellitus: the Atherosclerosis Risk in Communities (ARIC) study. Arch Intern Med 2010;170:1745-1751.

67 Chatterjee R, Colangelo LA, Yeh HC, Anderson CA, Daviglus ML, Liu K, Brancati FL: Potassium intake and risk of incident type 2 diabetes mellitus: the Coronary Artery Risk Development in Young Adults (CARDIA) study. Diabetologia 2012;55:1295-1303.

68 Chatterjee R, Biggs ML, de Boer IH, Brancati FL, Svetkey LP, Barzilay J, Djousse L, Ix JH, Kizer JR, Siscovick DS, Mozaffarian D, Edelman D, Mukamal KJ: Potassium and glucose measures in older adults: the Cardiovascular Health study. J Gerontol A Biol Sci Med Sci 2015;70:255-261. 